\title{
Identifying areas susceptible to desertification in the Brazilian northeast
}

\author{
R. M. S. P. Vieira ${ }^{1}$, J. Tomasella ${ }^{1,2}$, R. C. S. Alvalá ${ }^{2}$, M. F. Sestini ${ }^{1}$, A. G. Affonso ${ }^{1}$, D. A. Rodriguez ${ }^{1}$, A. A. Barbosa ${ }^{2}$, \\ A. P. M. A. Cunha ${ }^{2}$, G. F. Valles ${ }^{1}$, E. Crepani ${ }^{1}$, S. B. P. de Oliveira ${ }^{3}$, M. S. B. de Souza ${ }^{3}$, P. M. Calil ${ }^{4}$, \\ M. A. de Carvalho ${ }^{2}$, D. M. Valeriano ${ }^{1}$, F. C. B. Campello ${ }^{5}$, and M. O. Santana ${ }^{5}$ \\ ${ }^{1}$ Instituto Nacional de Pesquisas Espaciais, São José dos Campos, Brazil \\ ${ }^{2}$ Centro Nacional de Monitoramento e Alertas de Desastres Naturais, Cachoeira Paulista, Brazil \\ ${ }^{3}$ Fundação Cearense de Meteorologia e Recursos Hídricos, Fortaleza, Brazil \\ ${ }^{4}$ Secretaria de Agricultura Agropecuária e Abastecimento de Goiás, Goiânia, Brazil \\ ${ }^{5}$ Secretaria de Extrativismo e Desenvolvimento Rural Sustentável, Brasília, Brazil
}

Correspondence to: R. M. S. P. Vieira (rita.marcia@inpe.br)

Received: 4 November 2014 - Published in Solid Earth Discuss.: 10 December 2014

Revised: 11 February 2015 - Accepted: 13 February 2015 - Published: 18 March 2015

\begin{abstract}
Approximately $57 \%$ of the Brazilian northeast region is recognized as semi-arid land and has been undergoing intense land use processes in the last decades, which have resulted in severe degradation of its natural assets. Therefore, the objective of this study is to identify the areas that are susceptible to desertification in this region based on the 11 influencing factors of desertification (pedology, geology, geomorphology, topography data, land use and land cover change, aridity index, livestock density, rural population density, fire hot spot density, human development index, conservation units) which were simulated for two different periods: 2000 and 2010. Each indicator were assigned weights ranging from 1 to 2 (representing the best and the worst conditions), representing classes indicating low, moderate and high susceptibility to desertification. The results indicate that $94 \%$ of the Brazilian northeast region is under moderate to high susceptibility to desertification. The areas that were susceptible to soil desertification increased by approximately $4.6 \%\left(83.4 \mathrm{~km}^{2}\right)$ from 2000 to 2010 . The implementation of the methodology provides the technical basis for decisionmaking that involves mitigating actions and the first comprehensive national assessment within the United Nations Convention to Combat Desertification framework.
\end{abstract}

\section{Introduction}

Drylands (arid, semi-arid and dry sub-humid areas) cover approximately $41 \%$ of the Earth's surface and approximately 10 to $20 \%$ of these regions are experiencing degradation processes (Deichmann and Eklundh, 1991; Reynolds et al., 2007), resulting in a decline in agricultural productivity, loss of biodiversity and the breakdown of ecosystems. According to the United Nations Conference to Combat Desertification (UNCCD), when land degradation happens in the world's drylands it often creates desert-like conditions. Land degradation occurs everywhere but is defined as desertification when it occurs in the drylands, resulting from various factors, including climatic variations and human activities (UN, 1979; UNCCD, 2012). The vegetation is composed of scrublands patches (high plant cover) interspersed with herbaceous patches (low plant cover)(Aguiar and Sala, 1999). This heterogeneity is induced by overgrazing, one of the main causes of the increase of bare soil that facilitates water and wind erosion and accelerates the desertification process (Cerdà and Lavee, 1999; Kröpfl et al., 2013; Pulido-Fernández et al., 2013; Ziadat and Taimeh, 2013).

Forty-four percent of global agricultural areas and almost 2 billion people are located over the drylands, and the majority $(90 \%)$ are in developing countries (D'Odorico et al., 2013). Overexploitation of natural resources in extremely vulnerable regions can accelerate land degradation and desertification process, affecting ecosystem functions and de- 


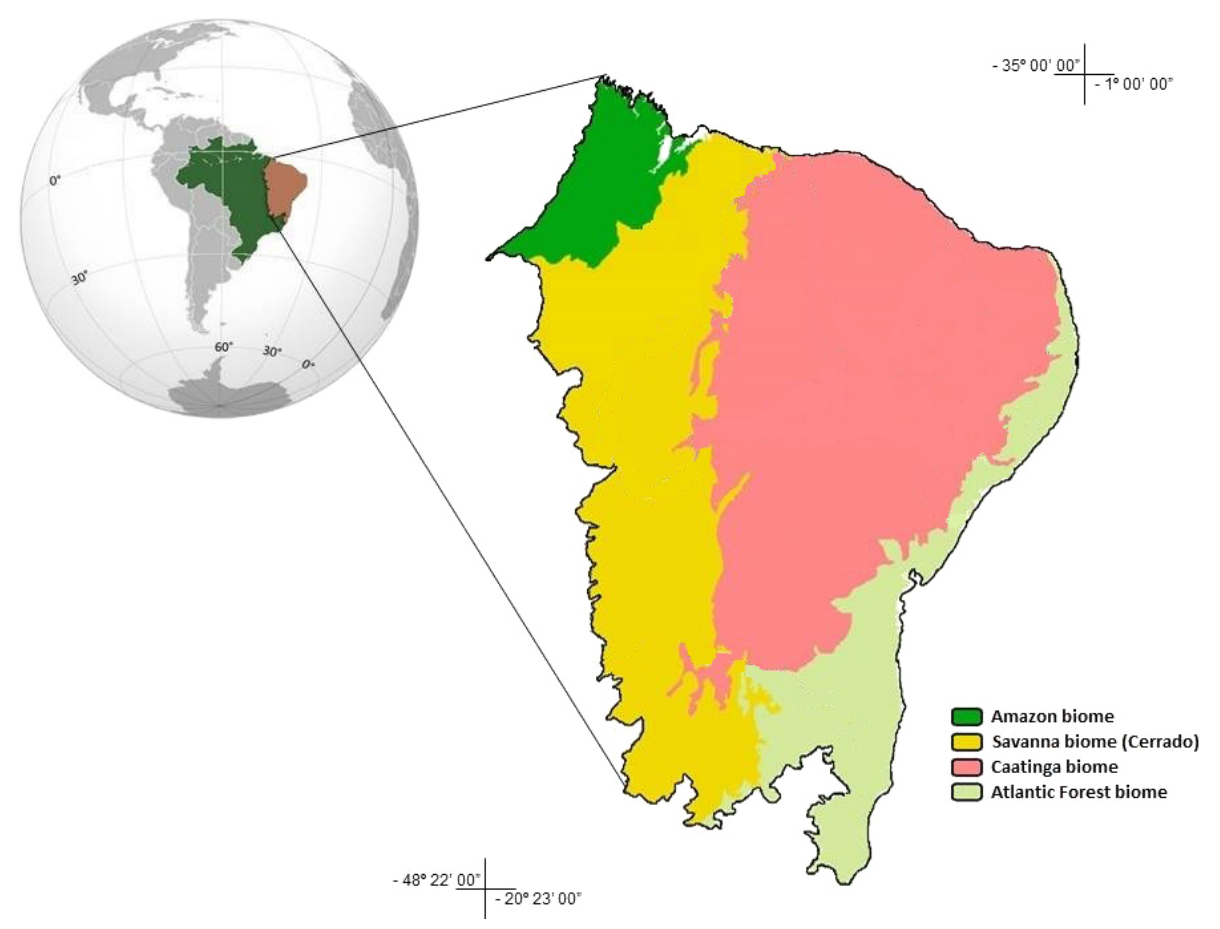

Figure 1. Study area location and its main biomes.

creasing productivity, biodiversity and landscape heterogeneity, and represents a major threat to the environment and human welfare (Mainguet, 1994; Reynolds and Stafford Smith, 2002; Montanarella, 2007; Salvati and Zitti, 2008; Cerdà et al., 2010; Santini et al., 2010; Kashaigili and Majaliwa, 2013; Pulido-Fernández et al., 2013; Bisaro et al., 2014).

In South America, the United Nations Convention to Combat Desertification report (ONU, 1997) concluded that, until 2025 , one-fifth of the productive land could be affected by the desertification process. The most susceptible areas are located in Argentina, Bolivia, Chile, Mexico, Peru and Brazil (Arellano-Sota et al., 1996). In Brazil, the most critical desertification hot spots are located in the semi-arid northeast. In this region the climate is one of the factors that control the desertification process. Soil type, geology, landscape, vegetation, socioeconomic factors and land management also are considered important aspects of this process (IBGE, 2004). The main causes of desertification in this region are (i) deforestation to produce fuel wood and explore clay deposits; (ii) intensive land use employing poor agricultural methods, such as slash and burn, harvesting and land clearing; (iii) salinization; and (iv) extensive herding and overgrazing (Nimer, 1988).

Considering that the Brazilian semi-arid region is the world's most populous dry land region (Marengo, 2008), with more than 53 million inhabitants and a human population density of approximately 34 inhabitants per $\mathrm{km}^{2}$ (IBGE, 2010), and that global climate change scenarios indicate that the region will be affected by increased aridity in the next century, this area is seen as one of the world's most vulnerable regions to climatic change (IPCC, 2007).

The UNCCD recognizes desertification as an environmental problem with huge human, social and economic costs (Hulme and Kelly, 1993).

The most accepted definition currently states that desertification is land degradation in arid, semi-arid and dry subhumid areas resulting from various factors, including climatic variations and human activities (UN, 1979). Due to the complex social interactions and the biophysical processes, the identification and assessment of the desertification areas have been addressed through a multidisciplinary framework across different spatial and temporal scales (e.g., Prince et al., 1998; Diouf and Lambin, 2001; Thornes, 2004; Santini et al., 2010).

Several methods have been successfully applied for desertification analysis based on indicators and indices (Kepner et al., 2006; Sommer et al., 2011). For instance, the MEDALUS methodology, developed for the European Mediterranean environment, is widely used because of its simplicity and flexibility. The MEDALUS methodology is based on the environmentally sensitive area index (ESAI; Parvari et al., 2011; Salvati et al., 2011; Izzo et al., 2013; Jafari and Bakhshandehmeh, 2013). In order to identify areas potentially affected by land degradation, the method analyzes four main variables: climate, soil, vegetation and land management (Kosmas et al., 1999, 2006; Lavado Contador et al., 2009). It has been validated on regional and local scales (Basso et al., 2000; Brandt et al., 2003; Salvati and Bajocco, 2011) and was 
Table 1. Indicators of land degradation/desertification.

\begin{tabular}{lrrr}
\hline Indicators & Scale/Spatial resolution & Period & Source \\
\hline Geology & $1: 500000 / 90 \mathrm{~m}$ & 2010 & INPE/MMA \\
Geomorphology & $1: 500000 / 90 \mathrm{~m}$ & 2010 & INPE/MMA \\
Pedology & $1: 500000 / 90 \mathrm{~m}$ & 2010 & INPE/MMA \\
Land use and land cover & $1: 500000 / 90 \mathrm{~m}$ & 2000 and 2010 & INPE/MMA \\
Aridity index & $1: 500000 / 5 \mathrm{~km}$ & $1970-2000$ & INMET/CPTEC \\
Slope angle & $1: 500000 / 90 \mathrm{~m}$ & 2010 & INPE \\
Rural population density & Per municipality & 2000 and 2010 & IBGE \\
Livestock density & Per municipality & 2000 and 2010 & IBGE \\
Fire hot spot density & $1: 500000 / 1 \mathrm{~km}$ & $1999-2003$ and $2008-2012$ & CPTEC \\
Human development & Per municipality & 2000 and 2010 & FJP \\
Conservation units & $1: 500000 / 90 \mathrm{~m}$ & 2010 & MMA \\
\hline
\end{tabular}

CPTEC - Center for Weather Forecasting and Climate Research; INMET - National Institute of Meteorology; FJP - João Pinheiro Foundation, INPE - National Institute For Space Research; MMA- Ministry of the Environment; IBGE - Brazilian Institute of Geography and Statistics.

applied to quantify the impact of mitigation policies against desertification (Basso et al., 2012).

Symeonakis et al. (2014) estimated the environmental sensitivity areas on the island of Lesvos (Greece) through a modified ESAI, which included 10 additional parameters related to soil erosion, groundwater quality, demographic and grazing pressure, for two dates (1990 and 2000). This study identified areas that are critically sensitive on the eastern side of the island mainly due to human-related factors that were not previously identified.

Although several studies have been conducted to detect desertification or to identify the drivers (indicators) of the process in critical hot spots in the Brazilian northeast (Matallo Júnior, 2001; Lemos, 2001; Sampaio et al., 2003; Aquino and Oliveira, 2012), there have been no studies addressing the entire region.

Crepani et al. (1996) developed a methodology based on the concept of the eco-dynamic principles, proposed by Tricart (1977), and on the relationship between morphogenesis and pedogenesis to identify areas that are susceptible to soil erosion. The author provided an integrated view of the physical environment and the conceptual basis for developing human-nature relationships. However, this study did not include socioeconomic and management indicators as parameters that can influence soil loss.

Therefore, this paper presents a novel approach which integrates the MEDALUS project and the methodology developed by Crepani et al., 1996 to identify areas that are susceptible to desertification in the northeastern region of Brazil and the northern regions of the states of Minas Gerais and Espírito Santo by combining social, economic and environmental indices. This study was conducted considering two reference periods: early 2000s and 2010. The results will be useful for providing basic information for the diagnosis and prognosis of desertification in the region and providing sub- sidies for the technical support for mitigation and adaptation actions.

\section{Study area}

The study area is located in the equatorial zone $\left(1-21^{\circ} \mathrm{S}\right.$, $32-49^{\circ} \mathrm{W}$ ), totaling an area of $1797123 \mathrm{~km}^{2}$, which corresponds to $20 \%$ of the Brazilian territory (Fig. 1).

The climatology of the northeast of Brazil includes three different rainfall regimes: (i) in the south-southwest area, the rainy season occurs from October through February, which is associated with the displacement of cold fronts coming from the south; (ii) in the north of the region, rainfall occurs from February to May, which is associated with the southward movement of the Intertropical Convergence Zone; and finally, (iii) in a narrow area that is close to the coast at the east, the rainy season occurs from April through August, triggered by temperature differences between the oceans and the sea shore (Kousky, 1979; Marengo, 2008). The evaporation rate in the region is very high and can reach $1000 \mathrm{~mm} \mathrm{yr}^{-1}$ in the coastal region and up to $2000 \mathrm{~mm} \mathrm{yr}^{-1}$ in the interior (IICA, 2001), based on 11 stations distributed in the semiarid region and on historical series (Molle, 1989). Annual evaporation average is 2700 to $3300 \mathrm{~mm}$, with the highest values occurs from October to December and the lowest from April to June.

Because of the high evaporation rates and the short duration of the wet season, most of the rivers are temporary, and flash floods occur only during the rainy season (MMAIBAMA, 2010).

In the northeast region of Brazil, natural vegetation includes rainforests, riparian forests, savannas and montane forests, among others (Foury, 1972). However, the natural vegetation that dominates $62 \%$ of Brazilian semi-arid region is caatinga (MMA, 2007). Caatinga vegetation is composed of shrubs and small trees, usually thorny and decidu- 
Table 2. Land use and land cover classes.

\begin{tabular}{ll}
\hline Land use and land cover classes & Description \\
\hline Evergreen forest & Evergreen broadleaf closed/open \\
Water body & Rivers, streams, canals, lakes, ponds or puddles \\
Beach & Beach area \\
Seasonal forest & Type of forest characterized by trees that seasonally shed their leaves \\
Restinga & Herbaceous and arbustive vegetation, distributed along the coastal zone \\
Urban area & Cities and towns \\
Savanna (Cerrado) & Grasslands, shrublands and woodlands \\
Fluviomarine & Mangrove \\
Alluvial & Similar characteristics to the evergreen forest but differs \\
& because of its physiographical position (alluvial plain) \\
Campo Maior complex & Prevailingly herbaceous vegetation; presence of carnaubais (coconut type) in flood plains \\
Steppe Savanna (caatinga) & Vegetation typical of the Brazilian semi-arid region characterized by \\
& xeric shrubland and thorn forest that primarily consists of small, \\
thorny trees that shed their leaves seasonally \\
Pasture & Producing shrimp \\
Agriculture & Pasture area (both natural and planted) \\
Baixada Maranhense & Cultivated areas (temporally and permanent crops) \\
Bare soil & Low plain area that is flooded in the rainy season, creating large lagoons \\
Dunes & Bare soil areas without natural covering \\
Rock outcrops & Sand dunes along the coast \\
Salt fields & Exposed rock areas \\
\hline & Areas where sea salt is produced \\
\hline
\end{tabular}

ous, that lose their leaves in the early dry season. Caatinga is a highly dynamic ecosystem that responds quickly to climatic conditions. The dominant factor that controls the structure and distribution of vegetation is the precipitation, with an annual mean of 500-800 mm and high spatial and temporal variability (Hastenrath and Heller, 1977; Oliveira et al., 2006). Caatinga, in comparison with other xeric areas in South America, presents climatic distinctiveness that resulted in numerous important morphological and physiological adaptations to aridity by many species of plants (Mares et al., 1985). Nowadays, more than $10 \%$ of the semi-arid area has already undergone a very high degree of environmental degradation, being susceptible to desertification (Oyama and Nobre, 2004).

\section{Methods}

To identify areas susceptible to desertification, we evaluated 11 indicators of susceptibility to desertification (Table 1) based on previous studies of the area (Vasconcelos Sobrinho, 1978; Ferreira et al., 1994; Matallo Júnior, 2001; Lemos, 2001). From Table 1, each indicator was sub-divided into various uniform classes. Each class received a weight factor, related to the potential influence on desertification process, that ranged between 1 (low susceptibility) and 2 (high susceptibility), producing 11 susceptibility maps (SM). The weight factors were assigned based on previous analyses of the literature (Crepani et al., 1996, Torres et al., 2003; Alves,
2006; Santini et al., 2010; Symeonakis et al., 2013). These indicators were grouped into two groups as described below.

\subsection{Physical indicators}

\subsubsection{Slope data, geology, geomorphology and pedology maps}

The basic topographic data set used was a $30 \mathrm{~m}$ spatial resolution digital elevation model (DEM), derived from TOPADATA, which was developed based on Shuttle Radar Topography Mission data (Farr and Kobrick, 2000; Van Genderen et al., 1987). The DEM was processed to derive elevation and slope angle and used to identify breakline surface discontinuities where changes occurred in the vertical curvature which are linked to lithological, pedological, geomorphological and vegetation characteristics. Therefore, breaklines often indicate the boundary between adjacent units on a map.

Geomorphology and geology maps were extracted from RADAMBRASIL Project (Projeto RADAMBRASIL 19731981) and from the Geological Survey of Brazil (CPRM Companhia de Pesquisa de Recursos Minerais), both with a spatial scale of $1: 1000000$. These basic maps were digitized and then rescaled to the scale of 1:500000 using the processed DEM, following the procedure suggested by Valeriano and Rossetti (2012).

Soil maps (EMBRAPA, 1999) were rescaled from $1: 5000000$ to $1: 500000$ based on the topographic map information. The Brazilian System of Soil Classification 
is based on soil pedogenetic characteristics, and also uses morphological, physical, chemical and mineralogical criteria (Camargo et al., 1987). The system is hierarchical and "opened" which allows the inclusion of new classes and enables the classification of all soil types that occur in Brazil.

\subsubsection{Aridity index (AI)}

The aridity index is considered to be one of the most important indicators of areas that are susceptible to desertification (UNESCO, 1979; Sampaio et al., 2003). In this study, the AI was obtained by the following formula:

$\mathrm{AI}=P / \mathrm{PET}$,

where $P$ is the precipitation and PET is the potential evapotranspiration calculated using the Penman-Monteith equation (Monteith, 1965).

\subsection{Socioeconomic indicators}

\subsubsection{Land use and land cover maps}

Between 2000 and 2010, northeast Brazil was the fastestgrowing economic (IBGE, 2010) region of the country and has been undergone severe land use and land cover changes. Therefore, it is crucial to asses if the combination of both effects - fast growth and severe land use changes - have impacted the susceptibility to desertification/degradation of the region. Thus, 90 Landsat-TM images ( $30 \mathrm{~m}$ resolution) of the dry period (July to September) of 2010 and 2011 were selected and geocoded based on the orthorectified Landsat images from the Global Land Cover Facility (NASA). These images were used to update the land use and land cover map derived by the ProVeg Project (Vieira et al., 2013), which was based on Landsat images from 2000. Additionally, land use and land cover maps from the PROBIO (Project for Conservation and Sustainable Use of Biological Diversity) (MMA, 2007) project, with a spatial scale of $1: 500000$, and highresolution images from Google Earth were used as auxiliary data. The land use and land cover classes mapped in this study are presented on Table 2 .

\subsubsection{Rural population density}

These data were extracted from IBGE census data (available at http://downloads.ibge.gov.br/downloads_estatisticas.htm). The rural area boundaries and the number of inhabitants were defined considering information for both 2000 and 2010.

\subsubsection{Livestock density}

Livestock density data, based on the total number of cattle and goat herds per municipality in 2000 and 2010, were extracted from IBGE agricultural census.

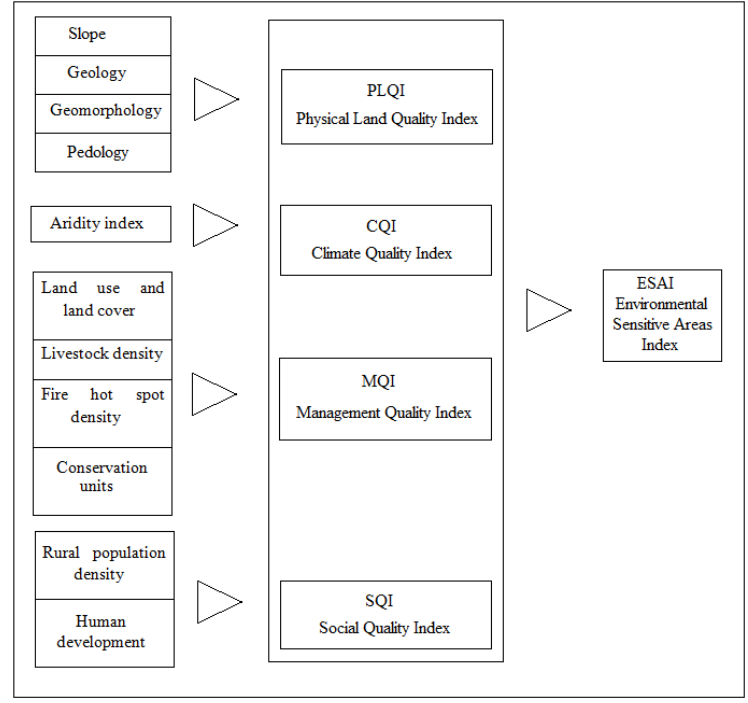

Figure 2. Combination of indicators for the determination of the ESAI; adapted from Benabderrahmane and Chenchouni (2010).

\subsubsection{Fire hot spot density}

Fire hot spot data were obtained from INPE's Fire Monitoring Project (INPE, 2012). Fire hot spot density maps were derived for two periods: (i) the average number of satellite hot spots from 1999 to 2003, which was used to represent the year 2000, and (ii) the average for the period 2008 to 2012, which was used as an indicator for the year 2010. To convert point data to continuous smooth surfaces, Kernel density estimation was applied to fire hot spots point using a $50 \mathrm{~km}$ radius (Koutsias et al., 2004; de la Riva et al., 2004). This estimator improves visualization and enables comparison with continuous environmental variables (Silverman, 1986).

\subsubsection{Conservation units}

Conservation unit data were obtained from the Ministry of the Environment. In the present study, the number of conservation units for 2000 and 2010 did not change. There are two basic categories of conservation units: integral protection units and the conservation units for sustainable use (Rocco, 2002). The former forbids the use of natural resources and includes national parks, ecological stations, biological reserves and wildlife sanctuaries. The latter includes national forests, extractive reserves and sustainable development reserves where the sustainable use and the management of natural resources are allowed under certain regulations.

\subsubsection{Human development index (HDI)}

The HDI indicators for the years 2000 and 2010 were obtained from the João Pinheiro Foundation (http://atlasbrasil. org.br/2013/). Population data, as well as HDI, are essential to understand the territorial dynamics. The calculation 
Table 3. Classes and weights of parameters used for environment quality assessment.

\begin{tabular}{|c|c|c|}
\hline $\begin{array}{l}\text { Susceptibility } \\
\text { class }\end{array}$ & Geomorphological types and features & $\begin{array}{l}\text { Susceptibility } \\
\text { weight }\end{array}$ \\
\hline \multirow[b]{2}{*}{ Low } & $\begin{array}{l}\text { Terrace formations structural and flat tops landforms; the rough- } \\
\text { ness of the topographic relief is characterized by being very } \\
\text { slightly dissected; flat relief and planation surface without intense } \\
\text { erosive action. }\end{array}$ & 1.00 \\
\hline & $\begin{array}{l}\text { Flat and convex tops landforms; the roughness of the topographic } \\
\text { relief is characterized by being lightly to moderately dissected; } \\
\text { flat relief and planation surface with significant erosive action; } \\
\text { slightly undulating relief with gentle slopes. }\end{array}$ & 1.25 \\
\hline Moderate & $\begin{array}{l}\text { Convex tops landforms; the roughness of the topographic relief } \\
\text { is characterized by being moderately dissected; undulating relief } \\
\text { with steep slopes. }\end{array}$ & 1.50 \\
\hline High & $\begin{array}{l}\text { Convex and sharp tops; the roughness of the topographic relief is } \\
\text { characterized by being highly dissected; strong undulating relief } \\
\text { with very steep slopes; karstic relief. }\end{array}$ & 1.75 \\
\hline \multicolumn{3}{|c|}{ Geology type } \\
\hline \multirow{7}{*}{ Low } & $\begin{array}{l}\text { Quartzite, metaquartzite, banded iron formation, metagranodior- } \\
\text { ite, metatonalite }\end{array}$ & 1.00 \\
\hline & $\begin{array}{l}\text { Rhyolite, granite, dacite, metasyenogranite, monzogranite, } \\
\text { syenogranite, magnetite, metadiorite, metagabbro }\end{array}$ & 1.05 \\
\hline & Granodiorite, quartz-diorite, granulite & 1.10 \\
\hline & Migmatite, gneiss, orthogneiss & 1.15 \\
\hline & Nepheline syenite, trachyte, quartz-monzonite, quartz-syenite & 1.20 \\
\hline & Andesite, basalt & 1.25 \\
\hline & Gabbro, anorthosite & 1.30 \\
\hline \multirow[t]{4}{*}{ Moderate } & Biotite, quartz-muscovite, itabirite, metabasite, mica schist & 1.35 \\
\hline & Amphibolite, kimberlite & 1.40 \\
\hline & Hornblende, tremolite & 1.45 \\
\hline & Schists & 1.50 \\
\hline \multirow{10}{*}{ High } & Phyllite, metasiltite & 1.55 \\
\hline & Slate rock, metargillite & 1.60 \\
\hline & Marble & 1.65 \\
\hline & Quartz arenites (sandstones), ortoquartizites & 1.70 \\
\hline & Conglomerates & 1.75 \\
\hline & Arkoses & 1.80 \\
\hline & Siltstones, Argillite & 1.85 \\
\hline & Shale & 1.90 \\
\hline & Limestone, dolostone & 1.95 \\
\hline & $\begin{array}{l}\text { Unconsolidated sediments (colluvial and alluvial deposits, sandy } \\
\text { deposits, etc.) }\end{array}$ & 2.00 \\
\hline
\end{tabular}


Table 3. Continued.

\begin{tabular}{lll}
\hline $\begin{array}{l}\text { Susceptibility } \\
\text { class }\end{array}$ & Geomorphological types and features & $\begin{array}{l}\text { Susceptibility } \\
\text { weight }\end{array}$ \\
\hline \multicolumn{1}{c}{ Soil type (EMBRAPA, 1999) } \\
\hline Low & Latosols, organic soils, hydromorphic soils, humic soils & 1.00 \\
\hline Moderate & $\begin{array}{l}\text { Podzolic soils, brunizem, planosol, brunizem, structured dusky } \\
\text { red earth }\end{array}$ & 1.33 \\
\hline High & Cambisol & 1.66 \\
& Non-cohesive soils, immature soils, & 2.00 \\
\hline & laterites, rocky outcrop & 1.00 \\
\hline Low & \multicolumn{1}{c}{ Slope (\%) } & 1.50 \\
Moderate & $6-18$ & 2.00 \\
\hline High & $>18$ & \\
\hline
\end{tabular}

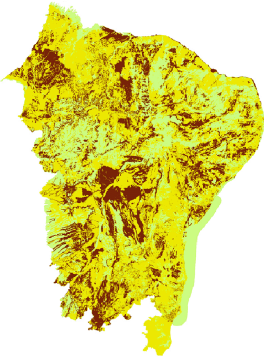

(a)

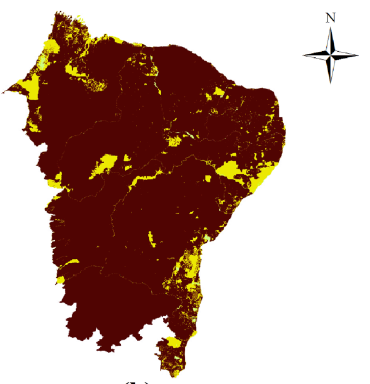

(b)

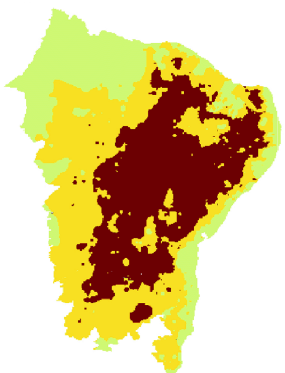

(c)

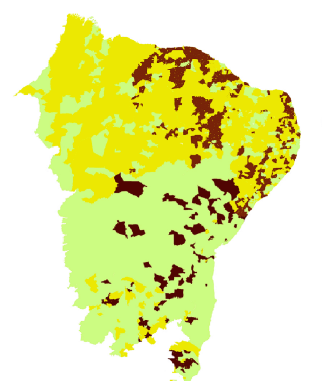

(d)

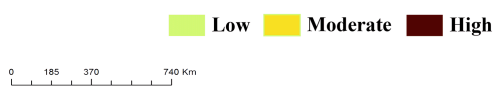

Figure 3. (a) Physical land quality index; (b) management quality index; (c) climate quality index; (d) social quality index.

of the HDI includes three kinds of data: longevity, education and economic income. HDI scale ranges from 0 to 1 , where values from 0 to 0.49 represent low HDI, 0.5 to 0.59 medium HDI, 0.60 to 0.79 high HDI, and 0.8 to 1.0 very high HDI. According to the Atlas of Human Development of Brazil 2013, developed by a partnership between United Nations Development Program (UNDP, 2010), the Institute of
Applied Economic Research and the João Pinheiros Foundation the Brazil have reduced the inequalities between its sub-indices of education, income and longevity in 2010.

\subsection{Environmentally sensitive area index}

The methodology used to map susceptible areas to desertification was based on the MEDALUS methodology (Mediterranean Desertification and Land Use, by Kosmas et al., 1999), which uses geometric means of environment-state and response indicators. Each index is estimated from a combination of indicators of desertification, which depends on geology, pedology, land management, human occupation and conservation policies (Fig. 2).

These maps were then grouped according to four quality indexes (Kosmas et al., 1999).

- Physical land quality index (PLQI):

$$
\text { PLQI }=\left(I_{\mathrm{s}} \cdot I_{\mathrm{g}} \cdot I_{\mathrm{gm}} \cdot I_{d}\right)^{1 / 4},
$$

where $I_{\mathrm{s}}$ is the soil SM, $I_{\mathrm{g}}$ is the geology $\mathrm{SM}, I_{\mathrm{gm}}$ is the geomorphology SM and $I_{d}$ is the slope SM.

- Management quality index (MQI):

$\mathrm{MQI}=\left(I_{\mathrm{uc}} \cdot I_{p} \cdot I_{\mathrm{fq}} \cdot I_{\mathrm{ucob}}\right)^{1 / 4}$,

where $I_{\mathrm{uc}}$ is conservation units SM, $I_{p}$ is the livestock density $\mathrm{SM}, I_{\mathrm{fq}}$ is the fire density $\mathrm{SM}$ and $I_{\mathrm{ucob}}$ is the land use and land cover SM.

- Climate quality index (CQI):

$\mathrm{CQI}=I_{\mathrm{a}}$,

where $I_{\mathrm{a}}$ is the aridity index SM. 
Table 4. Classes and weights of parameters used for management quality assessment.

\begin{tabular}{|c|c|c|}
\hline $\begin{array}{l}\text { Susceptibility } \\
\text { class }\end{array}$ & $\begin{array}{l}\text { Land use/land cover } \\
\text { change classes }\end{array}$ & $\begin{array}{l}\text { Susceptibility } \\
\text { weight }\end{array}$ \\
\hline \multirow{3}{*}{ Low } & Evergreen forest, water body, beach, urban area & 1.00 \\
\hline & Deciduous forest & 1.40 \\
\hline & Restinga & 1.45 \\
\hline \multirow{5}{*}{ Moderate } & Savanna (Cerrado), fluviomarine pioneer, alluvial pioneer & 1.50 \\
\hline & Complex of Campo Maior, Baixada Maranhense & 1.55 \\
\hline & Caatinga & 1.60 \\
\hline & Shrimp farming, pasture & 1.80 \\
\hline & Agriculture & 1.90 \\
\hline High & Bare soil, dunes, rocky outcrop & 2.00 \\
\hline \multicolumn{3}{|c|}{ Livestock density data } \\
\hline Low & 0 to 30 & 1.00 \\
\hline Moderate & 30 to 75 & 1.50 \\
\hline High & above 75 & 2.00 \\
\hline \multicolumn{3}{|c|}{ Fire density data } \\
\hline Low & 0 to 1000 & 1.00 \\
\hline Moderate & 1000 to 2000 & 1.50 \\
\hline High & above 2000 & 2.00 \\
\hline \multicolumn{3}{|c|}{ UC data } \\
\hline Low & Integral protection units & 1.00 \\
\hline Moderate & Conservation units for sustainable use & 1.50 \\
\hline High & Without conservation unit & 2.00 \\
\hline
\end{tabular}

- Social quality index (SQI):

$$
\mathrm{SQI}=\left(I_{\mathrm{HDI}} \cdot I_{\mathrm{Pop}}\right)^{1 / 2} \text {, }
$$

where $I_{\mathrm{HDI}}$ is the human development index SM and $I_{\text {pop }}$ is rural population density SM.

The geo-database was developed using SPRING (Câmara, et al., 1996).

Finally, to obtain an ESAI, the geometric mean is calculated among the variables inside each factor through the following equation:

$\mathrm{ESAI}=(\mathrm{PLQI} \cdot \mathrm{MQI} \cdot \mathrm{CQI} \cdot \mathrm{SQI})^{1 / 4}$.

Based on these calculations, three types of ESAs were assigned: (a) low-susceptibility areas (ESAI $1.00 \geq 1.25$ ), (b) moderate-susceptibility areas (ESAI $1.25 \geq 1.50$ ) and (c) high-susceptibility areas (ESAI > 1.50).

\subsection{Validation}

In this study, the 2010 susceptibility map was validated using the method proposed by Van Genderen et al. (1978). This method assumes that the probability of making $f$ interpretation errors when taking $x$ samples from a remote-sensingbased classification map follows a binomial probability distribution function. The method allows the determination of
Table 5. Classes and weights of parameters used for climate quality assessment.

\begin{tabular}{lrc}
\hline $\begin{array}{l}\text { Susceptibility } \\
\text { class }\end{array}$ & Climate types & $\begin{array}{c}\text { Susceptibility } \\
\text { weight }\end{array}$ \\
\hline Low & $\begin{array}{r}\text { Wet sub-humid } \\
\text { (AI above 0.65) }\end{array}$ & 1.00 \\
Moderate & $\begin{array}{r}\text { Dry sub-humid } \\
\text { High }\end{array}$ & 1.50 \\
& (AI between 0.51 to 0.65) \\
Semi-arid & 2.00 \\
\hline
\end{tabular}

the minimum sample size required for validating the map, avoiding the risk of accepting a map with low accuracy.

Based on this methodology, 110 random samples were selected from the low-, medium- and high-susceptibility classes and compared with high-resolution images from Google Earth (Ginevan, 1979; Congalton and Green, 1999) and in situ images. Thus, the points from high-susceptibility classes were compared to their corresponding images to observe the degraded areas of exposed soil. 


\section{Results and discussion}

This work presents the first effort to identify the areas that are most susceptible to desertification in the semi-arid region of Brazil through a system that enables continuous and integrated analysis of the factors that provide the best explanation of the desertification processes.

The weight factors assigned to each indicator are described in Tables 3, 4, 5 and 6.

Analyses from 11 indicators stress that areas with predominantly humid and sub-humid climate are potentially susceptible to desertification due to inadequate soil management, which is a key factor for adaptation and mitigation of climate change (IPCC, 2007).

On the MEDALUS methodology, variables like HDI and conservation units were not included. However, these two indicators were considered important in the semi-arid region Brazil based on the fact that the region has relatively low development indexes and several inadequate land uses practices, and previous studies in other regions of Brazil (Trancoso et al., 2010) have shown that conservation enforcement in protected areas is crucial for avoiding degradation.

\subsection{Physical land quality index}

In terms of soil types, the northeast and southern portions of the region are largely covered by Podzolic soils (23\%) that are more prone to erosion due to the low permeability of the B clayey horizon. Lithosols (21\% of the area) occur in the semi-arid region, associated with rock outcrops. Lastly, the Latosols $(18 \%)$ dominate the northwest region, associated with Savanna vegetation, where the relief is plain and favors the mechanized agriculture increasing soil compaction (Cavaliere et al., 2006; Araújo et al., 2007).

The eastern part of the study area is dominated by crystalline rocks. However, there is a predominance of sedimentary basins located in coastal regions and in the western part of the study area. To the south of the region, extensive karst formations can be found. Most of the study area consists of flat and undulating relief, but the occurrence of steep formations and the presence of inselbergs have also been noted.

According to the spatial distribution of the physical land quality index (Fig. 3a), $52 \%$ of the study area has a moderate susceptibility. The areas with high susceptibility are on soil types that are more vulnerable to erosion processes, such as podzols $(23 \%)$ and lithosols $(21 \%)$.

\subsection{Management quality index}

The analyses showed an increase of $3 \%$ of the area with high susceptibility for a period of 11 years between 2000 and 2010 (Table 7). Areas with high susceptibility reached $87 \%$ $\left(1571033 \mathrm{~km}^{2}\right)$ of the studied area in 2000 , while in 2010 the percentage increased to $90 \%\left(1622716 \mathrm{~km}^{2}\right)$. Among the factors that might be contributing to the increase in area
Table 6. Classes and weights of the parameters used for social quality assessment.

\begin{tabular}{lcr}
\hline $\begin{array}{l}\text { Susceptibility } \\
\text { class }\end{array}$ & $\begin{array}{c}\text { Human development index } \\
\text { Per municipality }\end{array}$ & $\begin{array}{r}\text { Susceptibility } \\
\text { weight }\end{array}$ \\
\hline Low & 0.70 to 1.00 & 1.00 \\
Moderate & 0.60 to 0.70 & 1.50 \\
High & 0 to 0.60 & 2.00 \\
\hline \multicolumn{3}{c}{ Rural population density } \\
\hline Low & 0 to 25 \\
Moderate & 25 to 50 & 1.00 \\
High & above 50 & 1.50 \\
\hline
\end{tabular}

are shrimp farming, agriculture, livestock and fire hot spots. Analyzing the results of use land and land cover, it is possible to observe that the natural vegetation is being replaced by pastures and agriculture. According to the land use/cover map developed by Vieira et al. (2013), the typical vegetation of the semi-arid of Brazil, known as caatinga, has been replaced by pasture and agricultural activities. Approximately $40 \%$ of the caatinga has been converted to these uses, and the remaining area is being transformed at a rate of $0.3 \%$ per year (IBAMA/MMA, 2010).

In recent years, agribusiness has become one of the most dynamic segments in the northeastern states with the production of fruits, such as papayas, melons, grapes, watermelons, pineapples and mangos. The activities related to shrimp farming covered an area of $69.7 \mathrm{~km}^{2}$ in 2000 , which increased to $136.7 \mathrm{~km}^{2}$ in 2010 . Northeastern Brazil is responsible for $94 \%$ of all shrimp production in Brazil (Ferreira, 2008).

Even though areas located in sub-humid and humid areas are less vulnerable from a climatic point of view, they are susceptible to land degradation and desertification due to inadequate land use and management. In the northwestern portion of study area, for example, the deforestation is one of main causes to land degradation. The natural vegetation is being replaced by pasture and agriculture, increasing from 106568 in 2000 to $143323 \mathrm{~km}^{2}$ in 2010 and from 10425 in 2000 to $20100 \mathrm{~km}^{2}$ in year 2010. In livestock areas of the region, fire is routinely used as a method for clearing land from bushes and for the re-establishment of pasture (Miranda, 2010). In the present work, the number of fire hot spot increased from 26181 in 2000 to 73429 in 2010.

\subsection{Climate quality index}

According to the climate quality index (Fig. 3c, Table 7), $42 \%$ of the area is a highly susceptible semi-arid climate, while $38 \%$ is classified as moderate susceptible dry subhumid. Finally, $20 \%$ of the area, where the climate is subhumid to humid, is considered as having a low susceptibil- 

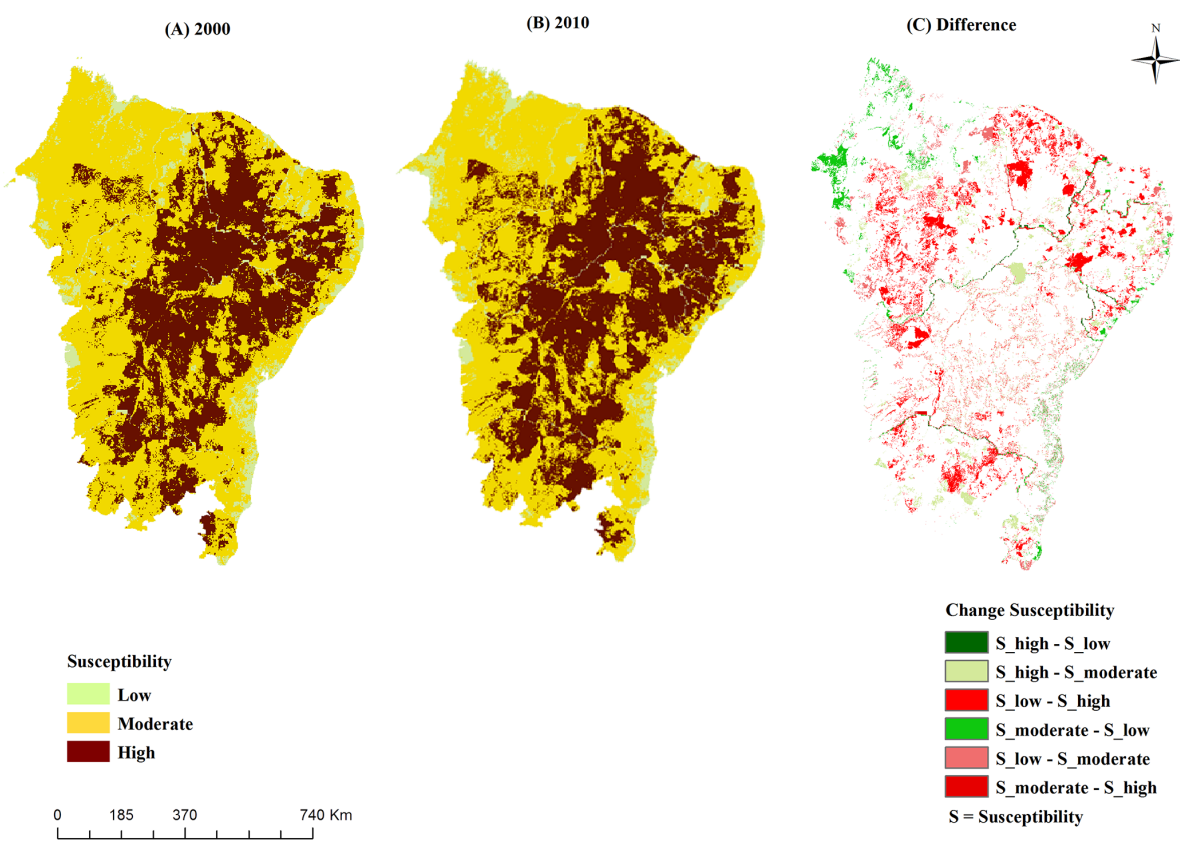

Figure 4. Environmental susceptibility area for (a) 2000 and (b) 2010. (c) Difference between 2000 and 2010.

Table 7. Percentage of the land area covered by each susceptibility class of the four quality indices in 2000 and 2010.

\begin{tabular}{lrrr}
\hline Index & Susceptibility class & $2000(\%)$ & $2010(\%)$ \\
\hline Physical land quality index & Low & 24.5 & 24.5 \\
(PLQI) & Moderate & 52.7 & 52.7 \\
& High & 22.9 & 22.9 \\
\hline Management quality index & Low & 1.0 & 0.8 \\
(MQI) & Moderate & 11.6 & 8.9 \\
& High & 87.4 & 90.3 \\
\hline Climate quality index & Low & 19.5 & 19.5 \\
(CQI) & Moderate & 38.2 & 38.2 \\
& High & 42.3 & 42.3 \\
\hline Social quality index & Low & 42.4 & 48.1 \\
(SQI) & Moderate & 34.8 & 32.9 \\
& High & 22.8 & 19.0 \\
\hline
\end{tabular}

ity. From a climatic point of view, rainfall exceeds $1250 \mathrm{~mm}$ in the coastal region annual. To the west, annual rainfall is around $1500 \mathrm{~mm}$, while in the semi-arid interior annual rainfall is less than $1000 \mathrm{~mm}$, ranging from 350 to $750 \mathrm{~mm}$ (IBGE, 1996).

\subsection{Social quality index}

The social quality index showed that $42 \%$ of the region had low susceptibility in 2000, while the value increased to $48 \%$ in 2010 (Table 7). According to IBGE (2010), the HDI improved in this period in response to the country's economic growth. The region is marked by socioeconomic inequality; the highest HDI is in the northern (0.682) and eastern (0.684) regions and the lowest is in the northeast (0.631).

\subsection{Susceptibility areas to desertification}

The areas susceptible to desertification in the Brazilian semiarid region for both 2000 and 2010, as well as the changes that occurred between these periods, are presented in Fig. 4. The results showed that $94 \%$ of the semi-arid region is moderately $(59.4 \%)$ or highly (35\%) environmentally sensitive for both periods: $2000(94.4 \%)$ and 2010 (94\%). Highsensitivity areas increased from 35 to $39.6 \%$, which corresponds to $83348 \mathrm{~km}^{2}$. Moderate regions decreased almost $5 \%\left(89856 \mathrm{~km}^{2}\right)$, while low-sensitivity areas increased from 
$5.6 \%$ (2000) to $6 \%$ (2010). The most susceptible areas were mapped, both in 2000 and 2010, in the central-eastern regions that include the four desertification hot spots officially recognized by the Brazilian Ministry of the Environment: Gilbués (PI), Irauçuba (CE), Cabrobó (PE) and Seridó (RN) (MMA, 2007).

The results also showed several areas with high susceptibility, specifically in the south of the study area. According to the field survey, desertification in this area is increasing due to inadequate soil management and indiscriminate deforestation (MMA, 2005). The human activities are the dominant factor for desertification expansion. However, in the northwest of the study area, several spots showed low susceptibility. Government incentives in the last decades have turned this region into a tropical fruit producer (Araujo and Silva, 2013).

From these results, it is clear that the management quality index is the main driver of desertification in the study region (Fig. 3b). Therefore, mitigation actions for reducing the susceptibility to degradation in the region depend heavily on changes in management practices towards more sustainable land use.

Finally, it is important to note that the validation results indicated that the environment susceptibility map has an accuracy of $85 \%$, which is considered acceptable due to the extent and complexity of the study area.

\section{Final considerations}

The environmentally sensitive area index calculated in the present study allowed a better understanding of the degradation/desertification process in the Brazilian semi-arid region. The study showed that desertification susceptibility ranges from moderate to high in the Brazilian semi-arid region.

From a climatic point of view, the humid and sub-humid areas have low vulnerability. However, when management issues associated with land use are taken into consideration, these areas become potentially susceptible to degradation.

The northwestern part of the study area is highly susceptible to land degradation due to inadequate soil management associated with intensive agricultural land expansion. In the last 50 years, the area received millions of migrants looking for better opportunities created by agriculture expansion.

This study is the first effort to produce a comprehensive diagnosis of the desertification processes for the entire region and combines the existing experience from previous studies in the region with a consolidated methodology. Additionally, new indicators were included in the methodology of this study, such as HDI (social indicator) and conservation units (management indicator), because previous knowledge indicated that they would be relevant in the study area.

In addition, it was possible to obtain a database with biophysical and social information on the same scale and reso- lution, which allowed the integrated analysis of the desertification indicators.

One of the major issues facing humanity today is the development of knowledge in regards to the occupation of land in regions affected by desertification in a sustainable way. Then it becomes critical to define adaptation alternatives for living in semi-arid regions. Furthermore, it can be applied in multi-scale studies, showing the magnitude of the risk in different areas and the factors that may contribute to triggering the process. The approach was based on the use of indicators that are routinely surveyed in the area, allowing for continuous monitoring of the desertification processes. The proposed methodology proved to be a useful, timely and costeffective tool to identify areas that are susceptible to degradation/desertification.

Acknowledgements. The authors are grateful to the Brazilian Ministry of the Environment and Inter-American Institute for Cooperation on Agriculture (IICA) for providing logistical and financial support, to Soil EMBRAPA, from Recife, for supplying the soil data and to the National Council for Scientific and Technological Development.

Edited by: A. Cerdà

\section{References}

Aguiar, M. R. and Sala, O. E.: Patch structure, dynamics and implications for the functioning of arid ecosystems, Trends Ecol. Evol., 14, 273-277, 1999.

Aquino, C. M. S. and Oliveira, J. B. V.: Avaliação de indicadores biofísicos de degradação/desertificação no núcleo de São Raimundo Nonato, Revista Equador (UFPI), 1, 44-59, 2012.

Alves, H. P. F.: Vulnerabilidade socioambiental na metrópole paulistana: uma análise sociodemográfica das situações de sobreposição espacial de problemas e riscos sociais e ambientais, Revista Brasileira de Estudos de População, 23, 43-59, 2006.

Araujo, G. J. F. de and Silva, M. M da.: Crescimento econômico no semiárido brasileiro: o caso do polo frutícola Petrolina/Juazeiro, Caminhos de Geografia, Uberlândia, 14, 246-264, 2013.

Araujo, R., Goedert, W. J., and Lacerda, M. P. C. Qualidade do solo sob diferentes usos e sob Cerrado nativo, Revista Brasileira de Ciência do Solo, 31, 1099-1108, 2007.

Arellano-Sota, C., Frisk, T., Izquierdo, J., Prieto-Celi, M., Thelen, K. D., and Vita, A.: FAO/UNEP - Program on desertification control in Latin America and the Caribbean, Desertification Control Bulletin, Nairobi, 29, 56-62, 1996.

Benabderrahmane, M. C. and Chenchouni, H.: Assessing environmental sensitivity areas to desertification in eastern Algeria using Mediterranean Desertification and Land Use "MEDALUS" model, Int. J. Sustain. Water Environ. Sys., 1, 5-10, 2010.

Basso, B., De Simone, L., Cammarano, D., Martin, E. C, Margiotta, S., Grace, P. R., Yeh, M. L., and Chou, T. Y.: Evaluating Responses to Land Degradation Mitigation Measures in Southern Italy, Int. J. Environ. Res., 6, 367-380, 2012. 
Basso, F., Bove, E., Dumontet, S., Ferrara, A., Pisante, M., Quaranta, G., and Taberner, M.: Evaluating environmental sensitivity at the basin scale through the use of geographic information systems and remotely sensed data: an example covering the Agri basin (Southern Italy), Catena, 40, 19-35, 2000.

Bisaro, A., Kirk, M., Zdruli, M., Zdruli, P., and Zimmermann, W.: Global drivers setting desertification research priorities: insights from a stakeholder consultation forum, Land Degrad. Dev., 25, 5-16, doi:10.1002/ldr.2220, 2014.

Brandt, J., Geeson, N., and Imeson, A.: A desertification indicator system for Mediterranean Europe, DESERTLINKS Project, UK, 2003.

Câmara, G., Souza, R. C. M., Freitas, U. M., and Garrido, J.: SPRING: Integrating Remote Sensing and GIS by ObjectOriented Data Modelling, Computer \& Graphics, 20, 395-403, 1996.

Camargo, M. N., Klamt, E., and Kauffman, J. H.: Soil classification as used in Brazilian soil surveys, ISRIC, Wageningen, Annual Report, 1987.

Cavalieri, K. M. V., Tormena, C. A., Vidigal Filho, P. S., Gonçalves, A. C. A., and Costa, A. C. S.: Efeitos de sistemas de preparo nas propriedades físicas de um Latossolo Vermelho distrófico, Revista Brasileira de Ciência do Solo, Viçosa, 30, 137-147, 2006.

Cerdà, A. and Lavée, H.: The effect of grazing on soil and water losses under arid and mediterranean climates, Implications for desertification, Pirineos, 153-154, 159-174, 1999.

Cerdà, A., Lavee, H., Romero-Diaz, A., Hooke, J., and Montanarella, L.: Soil erosion and degradation in Mediterraneantype ecosystems preface, Land Degrad. Dev., 21, 71-74, doi:10.1002/ldr.968, 2010.

Congalton, R. G. and Mead, R. A.: A quantitative method to test for consistency and correctness, in: Photointerpretaion, Photogrametric Engineering and Remote Sensing, 49, 69-74, 1983.

Congalton, R. G. and Green, K.: Assessing the accuracy of remotely sensed data: principles and practices, Boca Raton: CRC Lewis Press, 137 pp., 1999.

Crepani, E., Medeiros, J. S., Azevedo, L. G, Duarte V., Hernandez, P., and Florenzano, T.: Curso de Sensoriamento Remoto Aplicado ao Zoneamento Ecológico-Econômico, INPE, São José dos Campos-SP, 1996.

De la Riva, J., Perez-Cabello, F., Lana Renault, N., and Koutsias, N.: Mapping forest fire occurrence at a regional scale, Remote Sens. Environ., 92, 363-369, 2004.

Deichmann, U. and Eklundh, L.: Global Digital Datasets for Land Degradation Studies: A GIS Approach, GRID Case Study Series, 4, 1991.

Departamento Nacional da Produção Mineral - DNPM: Projeto RADAMBRASIL - Levantamento dos Recursos Naturais, Vol. 1, 2, 3, 4 e 21, Geomorfologia, 1973-1981.

Diouf, A. and Lambin, E. F.: Monitoring land-cover changes in semi-arid regions: remote sensing and field observations in the Ferlo, Senegal, J. Arid Environ., 48, 129-148, doi:10.1006/jare.2000.0744, 2001.

D’Odorico, P., Carr, J. A., Laio, F., Ridolfi, L., and Vandoni, S.: Feeding humanity through global food trade, 2, 458-469, doi:10.1002/2014EF000250, 2013.

EMBRAPA: Centro Nacional de Pesquisa de Solos, Sistema brasileiro de classificação de solos, Brasília, Embrapa Produção de Informação, Rio de Janeiro, 412 pp., 1999.
Farr, T. and Kobrick, M.: Shuttle radar topography mission produces a wealthy of data, American Geophysical Union Eos, 81, 583585, doi:10.1029/EO081i048p00583, 2000.

Ferreira, D. G, Melo, H. P., Neto, F. R. R, Nascimento, P. J. S., and Rodrigues, V.: Avaliação do quadro de desertificação no Nordeste do Brasil: diagnósticos e perspectivas, in: Conferência Nacional de Desertificação, Fundação Esquel Brasil, Brasília, 1994, 7-55, 1994.

Ferreira, D. G., Melo, J. V., and Costa Neto L. X.: Influência da Carcinicultura sobre a salinização do solo em áreas do município de Guamaré/RN, Holos, 24, 72-80, 2008.

Foury, A. P.: As matas do nordeste brasileiro e sua importância econômica, Boletim de Geografia, 31, 14-131, 1972.

Ginevan, M.: Testing land use map accuracy: another look, Photogrammetric Engineering and Remote Sensing, 45, 1371-1377, 1979.

Hastenrath, S. and Heller, L.: Dynamics of climatic hazards in northeast Brazil, Quart. J. Roy. Meteor. Soc, 103, 77-92, 1977.

Hulme, M. and Kelly, M.: Exploring the links between: Desertification and Climate Change, Environment, 35, 5-11, doi:10.1080/00139157.1993.9929106, 1993.

IBAMA/MMA: Monitoramento do desmatamento nos biomas brasileiros por satélites, Monitoramento do Bioma Caatinga 2002 a 2008, Centro de Sensoriamento Remoto - CSR/IBAMA: http://www.ambiente.gov.br/estruturas/sbf_chm_rbbio/ _arquivos/relatrio_tcnico_caatinga_72.pdf (last access: 10 March 2012), 2010.

IBGE: Recursos Naturais e Meio Ambiente: Uma visão do Brasil, Departamento de Recursos Naturais e Estudos Ambientais, 2, Rio de Janeiro, 208 pp., 1996.

IBGE: Estudos de pesquisas e informações geográficas, Coordenação de Recursos Naturais e Estudos Ambientais e Coordenação de Geografia, 4, 389 pp., 2004.

IBGE: Estados: População, Instituto Brasileiro de Geografia, Rio de Janeiro: http://censo2010.ibge.gov.br/apps/atlas/ (last access: 10 April 2013), 2010.

IPCC: Climate change 2007: the physical science basis, Contribution of Working Group I to the Fourth Assessment Report of the Intergovernmental Panel on Climate Change, edited by: Solomon, S., Qin, D., Manning, M., Chen, Z., Marquis, M., Averyt, K. B., Tignor, M., and Miller, H. L., Cambridge University Press, Cambridge, United Kingdom and New York, NY, USA, 2007.

INPE: Instituto Nacional de Pesquisas Espaciais, Portal do Monitoramento de Queimadas e Incêndios: http://www.inpe.br/ queimadas, last access: 2 August 2012.

IICA: Instituto Interamericano de Cooperação para Agricultura, Projeto Áridas: https://books.google.com.br/books?id= NO8qAAAAYAAJ, last access: 27 March 2011.

Izzo, M., Araujo, N., Aucelli, P. P. C., Maratea, A., and Sánchez, A.: Land sensitivity to desertification in the Dominican Republic: an adaptation of the ESA methodology, Land Degrad. Dev., 24, 486-498, 2013.

Jafari, R. and Bakhshandehmehr, L.: Quantitative mapping and assessment of environmentally sensitive areas to desertification in central Iran, Land Degrad. Dev., 2013.

Kashaigili, J. J. and Majaliwa, A. M.: Implications of land use and land cover changes on hydrological regimes of the Malagarasi 
River, Tanzania, Journal of Agricultural Sciences and Application (JASA), 2, 45-50, doi:10.1002/ldr.2241, 2013.

Kepner, W. G., Rubio, J. L., Mouat, D. A., and Pedrazzini, F. (Eds.): Desertification in the Mediterranean Region: A Security Issue, NATO Security through Science Series-C, Environmental Security, Springer: Dordrecht, the Netherlands, 2006.

Kosmas, C., Kirkby, M., and Geeson, N.: Manual on key indicators of desertification and mapping environmentally sensitive areas to desertification, European Commission: Brussels, 1999.

Kosmas, C., Tsara, M., Moustakas, N., Kosma, D., and Yassoglou, N.: Environmental sensitive areas and indicators of desertification In Desertification in the Mediterranean region, A security issue, NATO Security Through Science Series, 3, 2006.

Koutsias, N., Kalabokidis, K. D, and Allgower, B.: Fire occurrence patterns at landscape level: beyond positional accuracy of ignition points with kernel density estimation methods, Nat. Resour. Modell., 17, 359-376, doi:10.1111/j.1939-7445.2004.tb00141.x, 2004.

Kousky, V. E.: Frontal influences on Northeast Brazil, Mon. Weather Rev., 107, 1140-1153, 1979.

Kröpfl, A. I., Cecchi, G. A., Villasuso, N. M., and Distel, R. A.: Degradation and recovery processes in Semi-Arid patchy rangelands of northern Patagonia, Argentina, Land Degrad. Dev., 24, 393-399, doi:10.1002/ldr.1145, 2013.

Lavado Contador, J. F., Schnabel, S., Gómez Gutiérrez, A., and Pulido Fernández, M.: Mapping sensitivity to land degradation in Extremadura, SW Spain, Land Degrad. Dev., 20, 129-144, doi:10.1002/ldr.884, 2009.

Lemos, J. J. S.: Níveis de degradação no Nordeste do brasileiro, Revista Econômica do Nordeste, 32, 406-429, 2001.

Mainguet, M.: What is Desertification?, Definitions and Evolution of the Concept, Desertification Natural Background and Human Mismanagement, Springer, Berlin, 1-16, 1994.

Mares, M. A., Willig, M. R., and Lacher, T.: The Brazilian caatinga in South American zoogeography: Tropical mammals in a dry region, J. Biogeogr., 12, 57-69, 1985.

Marengo, J. A.: Vulnerabilidade, impactos e adaptação à mudança do clima no semi-árido do Brasil, Parcerias Estratégicas, 27, 149-75, 2008.

Matallo Júnior, H.: Indicadores de desertificação: histórico e perspectivas, UNESCO, Brasília, 126 pp., 2001.

MMA - Ministério do Meio Ambiente: Programa de ação nacional de combate à desertificação e mitigação dos efeitos da seca PAN-BRASIL, Ministério do Meio Ambiente, Secretaria de Recursos Hídricos, 213 pp., 2005.

MMA - Ministério do Meio Ambiente: Atlas das áreas susceptíveis à desertificação do Brasil, Universidade Federal da Paraíba, Secretaria de Recursos Hídricos - SRH, 131 pp., 2007.

MMA-IBAMA - Ministério do Meio Ambiente: Monitoramento dos desmatamentos nos biomas brasileiros por satélite, Acordo de cooperação técnica MMA/IBAMA, Monitoramento do bioma Caatinga: 2002 a 2008, available at: http://siscom.ibama.gov.br/ monitorabiomas/caatinga/relatrio_tecnico_caatinga_72.pdf (last cccess: 10 July 2013), 2010.

Mirando, H. S.: Efeitos do regime do fogo sobre a estrutura de comunidades de cerrado: Resultados do projeto Fogo, Brasília-DF, IBAMA, 144 pp., 2010.

Molle, F.: Perdas por evaporação e infiltração em pequenos açudes, Série Brasil: SUDENE, Hidrologia, 25, 11-70, 1989.
Montanarella, L.: Trends in land degradation in Europe, edited by: Sivakumar, M. V. and N'diangui, N., Climate and land degradation, Berlin: Springer, 83-104, 2007.

Monteith, J. L.: Evaporation and Environment, in: The state and movement of water in living organism, 19th Symp., Soc. Exptl. Biol., 205-234, 1965.

Nimer E.: Desertificação: realidade ou mito?, Revista Brasileira de Geografia, 50, 7-39, 1988.

Oliveira, M. B. L., Santos, A. J. B., Manzi, A. O., Alvala, R. C. S., Correia, M. F., and Moura, M. S. B.: Exchanges of energy and carbon flux between caatinga vegetation and the atmosphere in northeastern Brazil, Rev. Bras. Meteor., 21, 166-174, 2006.

ONU: Convenção das Nações Unidas de Combate à Desertificação nos países afetados por seca grave e/ou desertificação, particularmente na África, Brasília, Ministério do Meio Ambiente, dos Recursos Hídricos e da Amazônia Legal, 89 pp., 1997.

Oyama, M. D. and Nobre, C. A.: Climatic consequences of a large-scale desertification in northeast Brazil: A GCM simulation study, J. Climate, 17, 3203-3213, 2004.

Parvari, S. H, Pahlavanravi, A., Nia, A. R. M., Dehvari, A., and Parvari, D.: Application of methodology for mapping environmentally sensitive areas (ESAs) to desertification in dry bed of Hamoun wetland (Iran), Int. J. Nat. Resour. Mar. Sci., 1, 65-80, 2011.

Pulido-Fernández, M., Schnabel, S., Lavado-Contador, J. F., Miralles Mellado, I., and Ortega-Pérez, R.: Soil organic matter of Iberian open woodland rangelands as influenced by vegetation cover and land management, Catena, 109, 13-24, doi:10.1016/j.catena.2013.05.002, 2013.

Prince, S. D., Colstoun, E. B., and Kravitz, L. L.: Evidence from rain-use efficiencies does not indicate extensive Sahelian desertification, Glob. Change Biol., 4, 359-374, doi:10.1046/j.13652486.1998.00158.x, 1998.

Reynolds, J. F. and Stafford, S. D. M.: Global Desertification: Do Humans Cause Deserts?, 88, Dahlem University Press, Berlin, 2002.

Reynolds, J. F., Stafford, S. D. M., Lambin, E. F., Turner, I. B. L., Mortimore, M., Batterbury, S. P. J., Downing, T. E, Dowlatabadi, H., Fernández, R. J, Herrick, J. E., HuberSannwald, E., Jiang, H., Leemans, R., Lynam, T., Maestre, F. T., Ayarza, M., and Walker, B.: Global desertification: building a science for dryland development, Science, 316, 847-851, doi:10.1126/science.1131634, 2007.

Rocco, R.: Legislação Brasileira do Meio Ambiente, DP\&A Editora, Rio de Janeiro, 238 pp., 2002.

Salvati, L. and Zitti, M.: Long term demographic dynamics along an urban-rural gradient: implications for land degradation, Biota, 8, 61-69, 2008.

Salvati, L., Bajocco, S., Ceccarelli, T., Zitti, M., and Perini, L.: Towards a process based evaluation of land susceptibility to soil degradation in Italy, Ecol. Indic., 11, 1216-1227, 2011.

Santini, M., Caccamo, G., Laurenti, A., Noce, S., and Valentini, R.: A multicomponent GIS framework for desertification risk assessment by an integrated index, Appl. Geogr., 30, 394-415, doi:10.1016/j.apgeog.2009.11.003, 2010.

Sampaio, E. V. S. B, Araújo, M. S. B., and Sampaio, Y. S. B.: Propensão à desertificação no semi-árido brasileiro, Revista de Geografia, 22, 59-76, 2003. 
Silverman, B. W.: Density estimation for statistics and data analysis, Chapman and Hall, 1986.

Sommer, S., Zucca, C., Grainger, A., Cherlet, M., Zougmore, R., Sokona, Y., Hill, J., Della Peruta, R., Roehrig, J., and Wang, G.: Application of indicator systems for monitoring and assessment of desertification from national to global scales, Land Degrad. Dev., 22, 184-197, doi:10.1002/ldr.1084, 2011.

Symeonakis, E., Karathanasi, N., Koukoulas, S., and Panagopoulos, G.: Monitoring Sensitivity to land degradation and desertification with the environmentally sensitive area index: the case of Lesvos Island, Land Degrad. Dev., 22, 184-197, doi:10.1002/ldr.2285, 2014.

Torres, H. G., Marques, E., Ferreira, M. P., and Bitar, S.: Pobreza e espaço: padrões de segregação em São Paulo, Estudos Avançados, IEA, 17, 97-128, 2003.

Thornes, J. B.: Stability and instability in the management of Mediterranean desertification, in: Environmental modelling: Finding simplicity in complexity, edited by: Wainwright, J. and Mulligan, M., Chichester, UK, Wiley, 303-315, 2004.

Trancoso, R., Filho, A. C., Tomasella, J., Schietti, J., Forsberg, B. R., and Miller, R. P.: Deforestation and conservation in major watersheds of the Brazilian Amazon, Environ. Conserv., 36, 277288, doi:10.1017/S0376892909990373, 2010.

Tricart, J.: Ecodinâmica, IBGE-SUPREN (Recursos Naturais e Meio Ambiente), 91 pp., 1977.

UNESCO - United Nations Educational: Scientific and Cultural Organization, Map of the world distribution of arid regions: Map at scale $1: 25000000$ with explanatory note, MAB Technical Notes 7, UNESCO, 1979.
United Nations Development Programme (UNDP): Institute of Applied Economic Research (IPEA), Brazilian Institute of Geography and Statistics (IBGE) \& João Pinheiro Foundation (FJP), 2010, Atlas of Human Development in Brazil, Brasília, DF: UNDP, 2010.

United Nations Convention to Combat Desertification (UNCCD) Regions: Africa, Bonn: UNCCD, available at: http://www.unccd. int/en/regional-access/Pages/countries.aspx ?place=_31 (last access: 05 May 2013), 2012.

Valeriano, M. M. and Rossetti, D. F.: TOPODATA: Brazilian full coverage refinement of SRTM data, Appl. Geogr., 32, 300-309, 2012.

Van Genderen, J. L., Lock, B. F., and Vass, P. A.: Remote Sensing: Statistical testing of thematic map accuracy, Remote Sens. Environ., 7, 3-14, 1978.

Vasconcelos Sobrinho, J. O.: Metodologia para a identificação de processos de desertificação, Manual de indicadores, SUDENEDDL, 20 pp., 1978.

Vieira, R. M. S. P, Cunha, A. P. M. A., Alvalá, R. C. S., Carvalho, V. C., Ferraz Neto, S., and Sestini, M. F.: Land use and land cover map of a semi-arid Region of Brazil for meteorological and climatic models, Revista Brasileira de Meteorologia, 28, 129-138, 2013.

Ziadat, F. M. and Taimeh, A. Y.: Effect of rainfall intensity, slope and land use and antecedent soil moisture on soil erosion in an arid environment, Land Degrad. Dev., 24, 582-590, doi:10.1002/ldr.2239, 2013. 